\title{
Swedish Religion Education: Objective but Marinated in Lutheran Protestantism?
}

\author{
JENNY BERGLUND \\ Södertörn University
}

\begin{abstract}
In this article, I use the experience of a Czech doctoral student to discuss why religion education in Sweden can be understood as both deeply Lutheran and at the same time neutral and objective. In doing this, I look at the present syllabus in religion education, point to some of the changes that have been made in relation to the previous syllabus, and highlight some of the controversies that arose when it was written in 2010. I also put Swedish religion education and Swedish educational system in a historical context, pointing to its relation to liberal theology and cultural Protestantism. In addition, I present how teacher education is organized for religion education teachers and how the academic Study of Religions has been an important part of this during recent decades. At the end of the article I reflect upon the protestant taste of Sweden's 'non-denominational and neutral' religion education.
\end{abstract}

Keywords: RE, Sweden, non-confessional religion education, syllabus, Church of Sweden, Lutheran Protestantism

A couple of years ago I was contacted by a doctoral student from the Czech Republic. She was writing her PhD about religious education (RE) in Sweden and had been doing fieldwork in different schools in a mid-sized town in the southern part of the country. On the phone she said that she was deeply puzzled about what she had experienced and wondered if we could meet. I agreed, and a couple of weeks later she turned up at my office. She told me that when starting her PhD project she had read much about the different models of RE in Europe. She had been fascinated by the Swedish one, which stands out in terms of being defined as compulsory, integrative, with no opt-out possibility, and includes teaching about different religions and 'nonreligious worldviews', is non-denominational, and described as objective.

When we met, she had been doing fieldwork in Swedish RE classrooms for 3 months. Her puzzlement was due to the fact that instead of finding the objective RE that she expected to find, she had found what she called 'the Mecca of Lutheranism'. She offered several examples to justify this 
statement: the school year follows the Christian Lutheran calendar; the Lutheran holidays are celebrated in schools, and the teachers she had met hardly had any knowledge about non-Lutheran or non-Christian holidays; teachers and students (with no exception) consistently talked about religion as 'faith'; many of the textbooks presented non-Lutheran Christianities, as well as Islam, Hinduism, Buddhism, etc., in exotic and/or negative terms, and Protestantism was typically described in liberal democratic terms, whereas other religions were cast as more authoritarian. On top of this, she was surprised to find that in some schools students learned psalms and performed Christian prayers, and that clergy from the Church of Sweden would be invited to talk about Christianity, while representatives from other denominations were not. She described the relationship between the stated goals of the national curriculum and actual syllabus as a 'contradiction in terms'. ${ }^{1}$

I was not surprised about what this doctoral student said, since I have had many discussions with teacher students coming back from their in-school practice with similar reflections. Although we should be cautious before generalizing about what religion education in Sweden actually looks like from this these experiences, since there of course are many other pictures, and ideals and practice often differ, nevertheless it still gives us a hint about a school subject that claims to have washed away its Lutheran marinade but where the taste still remains.

In this article, I will use the experience of the Czech doctoral student to discuss why religion education in Sweden can be understood as both deeply Lutheran and at the same time is presented as neutral and objective. In doing this, I will look at the present syllabus in religion education, point to some of the changes that have been made in relation to the previous syllabus, and highlight some of the controversies that arose when it was written in 2010. Then I will put not only Swedish religion education, but also the Swedish educational system in historical context, pointing to its relation to liberal theology and cultural Protestantism. Thirdly, I will present how teacher education is organized for religion education teachers and how Study of Religions during the last decades has been an important part of this. In the end of the article I will reflect upon the protestant taste of this 'non-denominational and neutral' religion education, and call for the need for further self-reflection, but also argue for the necessity of engagement for the study of religions in all forms of teacher education.

1 I met with this doctoral student in May and October 2011. 
As the observant reader will already have noted, I have chosen to use the term religion education instead of religious education. The reason is that I find it necessary to distinguish between the different ways that religion is taught in Europe. The term religious education is used for very many different kinds of school subjects, with quite different aims. In some countries it refers to a confessional school subject taught, for example, by representatives of the majority Church (such as in Poland), whereas in other countries it is used for non-confessional school subjects that include aspects from different religious traditions (such as in the UK). In other words, the term religion education is a choice made to illustrate the Swedish school subject's officially non-denominational character that is based on a Study of Religions approach (Jensen 2008). ${ }^{2}$ Before plunging into the syllabus of this school subject, some words are needed about the country in focus.

\section{A Welfare State}

Sweden's population is estimated at 9 million and the state is often characterized as a welfare state. The Swedish welfare state is based on a model with state institutions distributing social services at the same time as a private sector is maintained. This is important for our discussion, since schools, both public and so-called 'free-schools' [friskolor] (also called 'independent schools') are free of charge and financed by the state through taxes. Universities too are free of charge, and religious organisations can obtain financial support for some of their activities. In this welfare state model, the educational system has been a central institution, from the late 19th century aimed at including the whole population.

In 1860, conversion from the Lutheran state church was legalized, on condition that one entered another religious congregation, but it was not until 1951 that Swedish citizens enjoyed freedom from religion without losing their citizenship. In 1956, Sweden initiated the process of separating the state from the church, a process that was completed in 2000. Today, there is no longer a state church in Sweden, as there is in neighbouring Norway and Denmark; instead, the Lutheran former state church has been redefined as a national church (Svanberg \& Westerlund 2011).

2 A direct translation of the Swedish word Religionskunskap is 'knowledge about religion'. Since religion education keeps the abbreviation RE and is already established (Jensen 2008) I prefer not using the direct translation of the Swedish word. 


\section{The Present Syllabus LGR11}

In 2009/2010 a review of all National Syllabi for the Swedish school system was carried out. Society had changed and the Swedish school had become increasingly criticized for falling results in international evaluations. The national syllabi for many school subjects were criticized for being unspecific, and leaving too much space for the teachers to decide on the content on their own. In the 1994 syllabus, for example, it was stated that religion education teaching should include Christianity and 'established religions and new religious movements', but not specifically mentioning any by name (Skolverket 2001). Studies done by teacher students of religion education have shown that this vague reference was used by some teachers to ignore teaching about Islam (Lilja \& Sunnercranz 2005; Eriksson \& Roskvist 2005).

The review of syllabi has brought about some big changes for religion education. One general novelty is that for both primary, secondary and upper secondary school there is a more specified central content, and it has become clearer what should be addressed within the framework of each level in school. A clearer progression has also been introduced between levels In primary school, the focus is on the local community and storytelling, while at higher levels there is a greater emphasis on key ideas within the major world religions (Christianity, Judaism, Islam, Hinduism and Buddhism, according to the syllabus) as well as in secular worldviews, or 'outlooks of life' as they are called in the English-language documentation from the National Agency for Schools (Skolverket 2011a). ${ }^{3}$ Another major change is that in the new syllabus, the importance is stressed of teaching about internal variation within religions. This is a welcome change, since research on both textbooks and classroom practices has shown that religions are often pictured as 'closed boxes' where all adherents act and think in the same way (Berglund 2011a; Otterbeck 2005).

Each syllabus has a 'core content', which it is obligatory to teach in all schools (including the denominational ones). In years 1-3 there is a joint syllabus for 'social study subjects'. The core content that relates to religion includes the following points (from the official English translation):

- The role of Christianity in the school and in the local area in the past.

- Religions and places of worship in the local area.

3 'Outlooks on life' is the words that are used in the official translation of the National Syllabus. An alternative would be to use 'world views'. 
- Narratives about gods and heroes in ancient and Nordic mythology and how these can be looked at from a contemporary perspective.

- Some ceremonies, symbols and narratives in Christianity, Islam and Judaism.

- Some narratives from the Bible and their meaning, and also some of the most common psalms. (Skolverket 2011a.)

For years 4-6, there is a specific syllabus for religion education which states that the students should learn:

Religions and other outlooks on life

- Rituals and religiously motivated precepts, and also holy places and locations in Christianity and the other world religions of Islam, Judaism, Hinduism and Buddhism.

- Key ideas behind rituals, precepts and holy places in Christianity and the other world religions, such as those expressed in religious narratives in the Bible and other records.

- Narratives from ancient Scandinavian and the older Sami religion.

- The concept of religion and outlook on life.

Religion and society

- The importance of Christianity for values and culture in Swedish society, both earlier and now. Christian holidays and traditions linked to the ecclesiastical year, such as songs and psalms.

- How traces of ancient Scandinavian religion can be observed in today's society.

Identity and life issues

- How different life issues, such as what is important in life and what it means to be a good friend, are depicted in popular culture.

- How different life issues, such as views on love and what happens after death, are depicted in religions and other outlooks on life.

- What religions and other outlooks on life may mean for people's identity, their lifestyles and group affiliation.

Ethics

- Some ethical concepts, such as right and wrong, equality and solidarity.

- Daily moral questions concerning the identities, roles of girls and boys, and gender equality, sexuality, sexual orientation, and exclusion and violation of rights. (Skolverket 2011a.) 
For years 7-9:

Religions and other outlooks on life

- Key ideas and documents in Christianity and the distinctive features of the three main orientations of Christianity: Protestantism, Catholicism and Orthodoxy.

- Key ideas and documents in the world religions of Islam, Judaism, Hinduism and Buddhism.

- Varying interpretations and practices in world religions in today's society.

- The main features in the historical evolution of world religions.

- New religious movements, new religiousness and private religiousness and how this is expressed.

- Secular outlooks on life, such as humanism.

Religion and society

- Christianity in Sweden. From a single church to religious diversity and secularism.

- The relationship between society and religion in different times and places.

- The role of religion in some political events and conflicts from a critical perspective.

- Conflicts and opportunities in secular and pluralistic societies, such as over issues concerning freedom of religious expression, sexuality and views on gender equality.

Identity and life issues

- How different life issues, such as the purpose of life, relationships, love and sexuality, are depicted in popular culture.

- How religions and other outlooks on life can shape people's identities and lifestyles.

- Rites, such as baptism and confirmation, and their function in forming identity and a sense of community in religious and secular contexts.

Ethics

- Daily moral dilemmas. Analysis and argumentation based on ethical models, such as consequential and deontological ethics.

- Views of the good life and the good person are linked to different kinds of ethical reasoning, such as virtue ethics.

- Ethical questions and the view of people in some religions and other outlooks on life. 
- Ethical concepts which can be linked to questions concerning sustainable development, human rights and democratic values, such as freedom and responsibility. (Skolverket 2011a).

In upper secondary school, one course in religion education is obligatory. Students have the possibility to add a second course, but also to take a more extensive course of specialization if they want. The obligatory course in upper secondary school builds on the knowledge acquired during the previous nine years of obligatory schooling. The first sentences in the syllabus clearly show its departure point:

The subject of religion has its scientific roots primarily in the academic discipline of religious studies, and is by its nature interdisciplinary. It deals with how religions and outlooks on life are expressed in words and action, and how people formulate and relate to ethical and existential issues. (Skolverket 2011b.)

The aim of the subject is presented in the following way:

Teaching in the subject of religion should give students the opportunities to develop the following:

1. The ability to analyse religions and outlooks on life based on different interpretations and perspectives.

2. Knowledge of human identity in relation to religions and outlooks on life.

3. Knowledge of different views on the relationships between religion and science, and the ability to analyse these.

4. The ability to use ethical concepts, theories and models.

5. The ability to examine and analyse ethical issues in relation to Christianity, other religions and outlooks on life. (Skolverket 2011b.)

The curricula are, as we can see, goal-oriented, and do not give any instruction on how much time a teacher should spend on each topic within the school subject; this is left to each teacher's professional discretion and judgment. 


\section{The Politics of Psalms}

The syllabus was written by a group of experts consisting of scholars from Study of Religions, teachers of religion education, and representatives from the National Agency for Education (Skolverket). The process was not without controversies. Several drafts were made public on the Internet, where it was also possible for the public to offer comments. The syllabus was discussed both in the daily press and in several TV programs. Representatives of various Christian denominations were swift to criticize the early drafts, one such criticism being that no value distinction was made between Christianity and other religions. Jonas Svensson (2010a), who was a member in the group who wrote the syllabus, points out that no such value distinction was made precisely in order to maintain the principle of the non-denominational curriculum. Some other critics interpreted the lack of value distinction as implying that equal space should be given to all religions, which was not the intention, since there is no mention of time in any syllabus.

The National Agency for Education anticipated criticism from the politicians on this issue, and therefore wrote in some additional references to Christianity, but without any direct change in content. Jan Björklund, the Minister of Education, was still not satisfied, however, and considered that there was still inadequate emphasis on Christianity. The Minister then officially announced that he had overruled the National Agency for Education by adding the word Christianity separately where previously the term world religions had been used alone. For example, where the expert panel had proposed that the students should learn about 'rituals and religiously justified precepts as well as holy places and spaces in the world religions Christianity, Islam, Judaism, Hinduism and Buddhism', the government preferred: 'rituals and religiously justified precepts as well as holy places and spaces in Christianity and the other world religions: Islam, Judaism, Hinduism and Buddhism' (Löfstedt 2011a, 11). In response, Malin Löfstedt and Jonas Svensson, who were members of the expert panel, noted that although the Minister of Education had made symbolic changes, nothing had been removed from the initial proposal. Although very little was actually added, what was added is nonetheless interesting: Psalms. Children in grades 1-6 are now required to learn Psalms (Löfsted 2011a, 11; Svensson 2010b).

The way that the Minister of Education changed the proposed syllabus in religion education raises many questions about the 'neutrality' and 'non-denominational' character of Swedish religion education. By listing Christianity separately from the other world religions, a clear distinction is made between Christianity and the 'Others'. This is a distinction that is 
problematic, and goes against the critical research that has been carried out on religion education, where the distinction to separate a Christian 'we' from 'others' has been sharply criticised (see for example Otterbeck 2005). It is also a distinction that helps us to understand some of the questions raised by the Czech doctoral student, since it reflects an understanding of religion education with a specific flavour.

\section{A Compulsory School Subject}

Although the construction of the religion education programme for schools attracted much more media attention and political debate than that for any other school subject, religion education in Sweden has no special status. It is a school subject like all other school subjects. It is mandatory for all (since 1996), like maths, history, physical education, home economics, etc.

From a European perspective, however, compulsory religion education is a unique phenomenon. In almost all other European countries, it is possible to be exempted from the school subject that concerns religion, if the parents so wish. The compulsory nature of Swedish religion education, according to the National Agency for Education, is intended to be in line with the European Convention on Human Rights as long as Sweden can guarantee that 'information be conveyed in an objective and pluralistic manner' (Kilkelly 1999, 71). This character of religion education in Sweden has not been uncontroversial. It has been questioned from denominational points of view: members of various religious denominations of different strands have argued that non-denominational religion education is not education about religion and religions from a neutral point of view, but rather education into atheism or secularism. This is an argument that has been used to justify the right for parents to establish schools based on their own religious conviction by reference to the European Convention on Human Rights (Berglund 2010a). And as we saw from the reaction by the Czech doctoral student, she also, from a different perspective, questioned the neutrality of Swedish religion education: for her it is questionable because of its clear Protestant flavour. To understand this 'distinct flavour', we need to put religion education in a historical context.

\section{From Religious Instruction to Religion Education}

The Swedish school system has a long history of Christian religious instruction linked the former Lutheran State Church. Although schooling was made 
compulsory for all children in 1842, Sven Hartman notes that 'Swedes [had been] a reading people' long before that - a result of the Ecclesiastical Act of 1686, which charged parents and masters with the domestic responsibility of teaching their children and servants to read (Hartman 2007a, 260). At that time, religious instruction was the most important school subject, and this remained the case until a major curriculum revision in 1919, the starting point of what may be called the secularization of Swedish schools. The transformations in 1919 were, as Mette Buchardt has shown, to a large extent driven by representatives of liberal theology and cultural Protestantism ('neo-Protestantism') (Buchardt et al. 2013, 81; see also Skogar 2005). The idea was that liberal theology could offer a liberal science-based alternative to both Pentecostalism, which had in recent decades become well-established in Sweden, and the conservative layers in the state church. In addition, neoProtestantism was presented as an alternative to Social Democracy, which at this time was often viewed as leading to atheism. Later, however, when the Swedish Social Democrats came into office, they instead became partners in the process of transforming education (Buchardt 2013, 87). Liberal theologians, such as Archbishop Nathan Söderblom, aimed at 'humanising, socialising and culturalising Christianity by employing it in different social fields, e.g. the educational field. Their involvement contributed to secularisation in the meaning of a growing division between the state and church matters, e.g. the question of schooling' (Buchardt et al. 2013, 83). As a result, religious instruction was reduced by fifty percent (1919), other subjects were introduced to balance the difference, and '[f]ostering for national citizenship instead of the Lutheran faith became the task of the school system' (Hartman 2007b, 260).

As the 20th century proceeded, on-going social changes led to demands to further reduce the Christian emphasis in schools, and after many parliamentary debates, education in Swedish schools was named 'nondenominational' in the syllabus of 1962 (Löfstedt 2011c, 211). 1962 was also the year when the selective dual school system was abandoned, and a school for all introduced [allmän grundskola]. The school subject Christianity [Kristendom] was renamed Knowledge about Christianity [Kristendomskunskap], and it was stipulated that the teaching should be neutral and objective in terms of religion. Objectivity requirements meant that teachers should also teach about other religions and should not, under any circumstances, influence the students' beliefs. In terms of our marinade metaphor, confessional Lutheran teaching was wiped off and a more 'facts-based' school subject introduced (Skogar 2005, 41). 
Seven years later, in 1969, the subject's name was again changed, to Religionskunskap ('Religious Knowledge') The change in name confirms the transition from a denominational to a non-denominational school subject that prioritises teaching about religion, including different religions. In this period, religion education also shifted from being a primarily facts-oriented subject to a student-oriented one (Hartman 2011,30). This can be understood as a washing away of the last Lutheran marinade, thereby making an attempt to firmly establish religion education as a neutral and objective subject. But as we will see, not only are humans all coloured by culture, history and language, but also school subjects; and marinades may be washed away, but the taste remains.

In the years leading up to the next curriculum, $\operatorname{Lgr} 80$, there were further changes in terms of subject content. Educational research in this period started to focus on how children and young people reflect on religion and life questions. Through interviews with children, researchers were able to show that children think about life and death for example, already in early childhood (Hartman 2007a), and it became apparent that even small children wrestle with 'life questions'. This led to the development of the 'life question pedagogy' approach, which has had a major impact on Swedish religion education since this time (Löfstedt 2011b, 52).

During the late eighties and early nineties, Swedish society became increasingly multicultural. The increased diversity and pluralism is reflected in both the syllabus for religion education and the national curriculum from the period. In the syllabus we can, for example, see that teaching about non-Christian religions is given more emphasis. In order to weld together all students and teachers, despite their different cultural backgrounds, the curriculum of 1994 introduced values education in a new way (Skolverket 1994). Values such as freedom, equality and solidarity were (and still are) presented as the foundation that school should rest on. Everyone in school, both adults and children, should work to ensure that these 'fundamental values' are 'imparted and instilled' in all subjects. The present national curriculum contains the following statement, which was also part of the 1994 curriculum:

The inviolability of human life, individual freedom and integrity, the equal value of all people, equality between women and men and solidarity with the weak and vulnerable are all values that the school should represent and impart. In accordance with the ethics borne by Christian tradition and Western humanism, this is achieved by fostering in the individual a sense 
of justice, generosity of spirit, tolerance and responsibility. Teaching in the school should be non-denominational. (Skolverket 2011a, 9.) ${ }^{4}$

In accordance with Sweden's Education Act, the values outlined in the above quotation are meant to be achieved in all schools, both public and free schools (Skollagen i praktiken 2005). The 'objectivity' and 'neutrality' of education is not to be intruded upon by indoctrinating or tendentious modes of discourse, regardless of a school's profile - confessional or any other (Johansson $\&$ Persson 1996, 22). On top of these fundamental values, all schools have to reach the goals of the national syllabi in all school subjects, including religion education (see below). In pursuit of these aims, most schools with denominational profiles (i.e. Jewish, Christian and Muslim schools) arrange only a small number of hours per week for the introduction of their own religious instruction. In, for example, Muslim schools, this number amounts to one to three hours per week of Islamic religious education (IRE). And since there are no national syllabi for such subjects, local syllabi have to be written (for examples, see Berglund 2010a).

The reference to 'ethics borne by Christian tradition and Western humanism' in the national curriculum (see above) has provoked much debate, since the curriculum also states that education should be 'non-denominational'. The use of the term non-denominational (icke-konfessionell) in the above quotation is meant to imply that in the Swedish school system education is to be implemented in such a way that no particular worldview is prioritized, and students from all cultural, ethnic and religious backgrounds would feel comfortable to attend. This however, does not extend to the realm of the fundamental values, the mediation of which the national curriculum considers a primary task of Sweden's educational system.

Let's also return to our Czech doctoral student who called the curriculum a 'contradiction in terms' because of these parallel references both to Christianity and to being 'non-denominational'. One way of understanding this contradiction is by acknowledging the history of liberal theology in the development of modern Swedish education. It contributed to the secularization of education in the sense of a growing division between state and church matters by promoting a science-based education, but it also contributed to what has been described as a 'sacralization of the state' and a reconstituted relation between Christianity and the state (Buchardt 2013, unpublished paper). Buchardt explains:

4 This is the official English translation, the word used in Swedish for non-denominational is icke-konfessionell, which sometimes is translated into non-confessional. 
This duality seems to be what made the ideas workable to Social Democrat reformers who still draw on such ideas - basically a Neo-Lutheran idea put to work in interplay with the governing forces from not least the Social Democracies. The culturalization of religion seems to be partly the basis for dividing church and state matters and partly a way to maintain religion as a resource for creating cohesion between citizens and the state body. Cultural Protestantism in the Nordic states has thus, among other forces, contributed to the independence of modern schooling from the church institution. But it has also contributed to the fact that welfare state schooling cannot be understood as independent from meanings and forms of knowledge from the religious field. As such it might make sense to talk about a Nordic model of secularization - with Protestant ideas as a pivotal force. (Buchardt 2013, unpublished paper.)

The fostering of good Christians was the aim of the school system up until the beginning of the 19th century. In the 20th and 21st centuries, the foremost goal has instead become to foster good citizens, which the paragraph about fundamental values is an example of. In light of the Protestant model of secularisation, these fundamental values can be understood as an example of the sacralisation of the state described by Buchardt. The argument for this would be that to claim a certain 'value foundation' independent of religion is as much an expression of faith as any religion, since it makes a truth claim that is binding for everyone (see e.g. Osbeck \& Cöster 2005).

\section{A New Content Pedagogy Needed}

When the actual shift from Christian religious education to a non-denominational religion education was to be implemented, there was a need for a new way of teaching, and 'life question pedagogy' gained wide attention. 'Life questions' could be understood as the equivalent of existential questions. Sven Hartman, who developed the pedagogy, defines life questions like this:

A life question concerns the basic conditions for human life and for life in general. A life question is also an expression of a need to process and reflect on the experiences of the world and of the self in relation to the world and life in general. (Hartman 2007a, 71.)

Ideally, when teachers use life question pedagogy, the starting point should be the student's own life question. In other words, religion education be- 
comes a matter for the individuals concerned and their life issues, but in the framework of an academic Study of Religions perspective (Hartman 2007a, $53 \mathrm{ff}$.). Examples of questions used in this pedagogy would be: What is the meaning of life? What happens after death? Who are you and how would you like to be as a person? What is morally right? Such questions were found to engage both young children and teenagers, and the pedagogy became and still is a widely used way to approach different religions in the RE classroom. Life questions are supposed to be posed by the students to different religious traditions and outlooks of life, as well as to themselves. Through studying different religions and outlooks on life, the students should then try to find the answers to these questions in the religion they are studying, the underlying idea being that this would bring about understanding for different religions, but that it could also contribute to the students' own ideas about her or his life. The life questions are understood to be universally human. This is why they can be posed to all religions and non-religious worldviews, even though life for different individuals differs in many ways. Malin Löfstedt $(2011 b, 53)$ explains them as 'both contextual and universal', since the fact that people relate to them is considered a human universal, but in which way, how and when is seen as contextual.

The impact of life question pedagogy could thus be understood as an alternative to the more dogmatic heritage of Christian instruction. It was also in tune with the changes that took place throughout the school system in the 70 s, where the former authoritarian school gave way to a more democratic system. Taking the departure point from the children's own life questions was part of this change (Löfstedt 2011b, $51 \mathrm{ff}$.).

Here I also find it important to present some of the critique that has been raised against life question pedagogy, a critique that also makes it possible to understand this pedagogy in relation to some of the Czech doctoral student's questions. To begin, the pedagogy is based on an understanding of religion as a phenomenon that has importance for giving answers to a human being's 'life questions' that have to do with faith. This perspective is prioritized in relation to questions guiding what humans should eat, how they should dress, how one's home should be decorated or what rituals one has to perform, i.e. questions that are related to what we call 'lived religion'. Life questions that prioritize faith could be construed as being predominant within Christianity. Pia Böwadt (2009), who has studied the concept of 'life philosophy' which is central in Danish religious education, has shown how 'life philosophy' rests on a Lutheran Christian creation theology. The same could be said about the Swedish context, and consequently, also about life 
question pedagogy. Using life questions as the lens for the study of religions could, from this perspective, be understood as giving them a Lutheran taste. Secondly, the (presupposed) universality of these 'life questions' cannot be regarded as given. Even though it is possible to find answers to life questions within different religious traditions and secular 'outlooks of life', I would argue that the weight they are given in various traditions is different. A third point of criticism is that using life questions as a way to study religions could (unintentionally) give the impression that there is only one answer to the questions within each religion, a situation that can easily create stereotypes (Löfstedt 2011b, 57).

Representations of religions have been a much-discussed topic within Study of Religions. In line with such discussions, we may ask what happens to religious traditions when they are presented through the lens of life questions?

There are many benefits with life question pedagogy that need to be acknowledged. It is known to engage students, and it foregrounds perspectives in religions that children and teenagers do not find too difficult to understand, since the questions are supposed to relate to their own life (Löfstedt 2011b: 2011c). Despite that, much remains to be done in terms of avoiding stereotypes, bringing in the interpretative differences that exist within the different traditions, and an understanding of religions as lived phenomena. This is a challenge that needs to be taken up, and where scholars of the study of the religions have much to contribute.

\section{Teacher Education}

As already mentioned, the Czech doctoral student also asked what kind of teacher training the teachers of religion education get in Sweden. It is not possible to give one straightforward answer to this question, since it is organised very differently at different universities in the country. What is in common is that in Sweden, teachers at all levels of the schools system (pre-school teachers, leisure-time instructors, primary school teachers, secondary school teachers and upper secondary school teachers) are educated at universities and university colleges. Primary school teachers are educated to teach a range of school subjects. Religion education is, for them, often combined with history, civics and geography. At most universities the students for these 'social study subjects' study inter-disciplinary courses taught by scholars from the fields of history, Study of Religions, geography, political science and education. Students working towards a qualification 
for secondary and upper-secondary religion education study at Study of Religions departments. Some universities organize courses that are specifically designed for teacher education students, but at other universities teacher students study the same courses as any other student in Study of Religions. Courses about different religions from a history of religions perspective is in both cases always part of the teacher training, since the students must be able to teach according to the national curriculum. The number of semesters and credits required depends on their future level of teaching (2-4 semesters, i.e. 45-90 ECTS).

Since religion education is an obligatory, non-confessional school subject, taught at all levels of the school system, many teachers need to be trained. Departments of Study of Religions have the responsibility for the content and are involved in their training to varying degrees (depending on the level in the school system). One result of this is that there are Study of Religions departments at more than 20 universities or university colleges in Sweden. This is a very considerable number compared to many other European countries, in relation to the size of the country's population.

Södertörn University ${ }^{5}$, where I teach, offers several 'intercultural teacher education' programs. Courses on religion are also included in the teacher training for students who will not teach religion education; the justification for this arrangement is that knowledge about different religions is seen as being necessary for all teachers, on all levels, since all teachers will meet children, students, parents, colleagues, etc., who belong to different religious traditions or secular outlooks of life, and it is argued that studying religion from an academic point of view will help future teachers to better understanding the society they live in. In other words, Study of Religions is a field that gives important perspectives and knowledge to all future teachers; but perhaps this is also linked to the idea of studies of religion contributing to social cohesion? This arrangement is unique for Södertörn University, however, and somewhat surprisingly, few other Study of Religions departments are currently involved in teacher training for levels other than secondary and upper secondary schools.

\section{Reflexivity Needed}

While some degree of religious diversity has always existed in Swedish society, over the last few decades the ethnic and cultural composition of the country

5 See www.sh.se/studyofreligions 
has undergone rapid transformation. Parallel to this, religion education in Sweden has also, as we have seen, gone through changes.

Although the self-image of the Swedish school system (and also of Swedish society in general ${ }^{6}$ ) is one of objectivity and neutrality, it is important to recognize the phenomenon that our doctoral student from the Czech Republic encountered when studying Swedish religion education. Through her questions, it becomes apparent that what from an inside-Sweden perspective is presented as neutral and objective may be understood from an outside perspective as deeply Lutheran: not only in terms of the factual history of the country, but also in terms of how people think and talk about religion in society, how religion is taught and holidays are celebrated in schools, how institutions are built, who gets subsidised by the state, etc. Sweden is a society that can be described as a society marinated in Lutheran Christianity, officially claiming to have washed away the marinade, but having problems in admitting that the taste abides.

In recent scientific thinking, the possibility of neutrality and objectivity in research has been severely questioned, and redefined in a way where the role and position of the researcher is frankly acknowledged (see for example Agar 1996; Lofland 2006, 16). This is a perspective that Study of Religions needs to further highlight in teacher training. Just as a researcher doing fieldwork is not a distant observer and 'transmitter' of knowledge about religion, a teacher is not a distant transmitter of objective facts (Berglund 2011b); she or he is an interactive participant in the field of education who needs to make reflective choices about what and how to teach (Berglund 2010b, 50).

When educating future teachers, it is important to discuss the concepts of objectivity, neutrality and non-denominational teaching. This cannot be done in a simplistic way, which I fear is often the case. Perspectivism, selfreflection, methodological agnosticism and contextualization have to be brought into the discussion on what non-denominational teaching means in a 'post-Lutheran majority culture' (Thurfjell 2011).

On top of this, we need to discuss what it actually means that we, like our institutions, are shaped by culture, history and language in an ines-

\footnotetext{
6 Note that neutrality brings about specific connotations in Sweden: The neutrality of the country has been and still is a well-established part of the national self-image. Since the early $19^{\text {th }}$ century Sweden has, for example, been internationally known for its policy of neutrality in terms of armed conflicts. For generations of Swedes neutrality in foreign policy has been something obvious and positive despite the problems of upholding the rhetoric when debated and challenged during for example World War II or in relation to NATO.
} 
capable way, and that ideas about non-confessionality and objectivity also have a cultural history and are not neutral. These are perspectives Study of Religions can provide, not only for religion education teachers, but also in other fields of teacher education.

Bibliography

Agar, Michael H.

1996 The professional stranger. An Informal Introduction to Ethnography. Bingley: Emerald Publishing.

\section{Berglund, Jenny}

2010a Teaching Islam, Islamic Religious Education in Sweden. Munster: Waxmann.

2010b Religionsdidaktik. - Jonas Svensson \& Stefan Arvidsson (eds), Människor \& Makter, 2.0, 50-55. Högskolan i Halmstad.

2011a Etnografiska glasögon på religion i vardagen. - Malin Löfstedt (ed.), Religionsdidaktik: Mångfald, livsfrågor och etik i skolan, 125-140. Lund: Studentlitteratur.

2011b IRU på muslimska friskolor, en översättning av islam till det svenska skolsystemet. - Peter Strandbrink \& Beatriz Lindqvist \& Håkan Forsberg (eds), Tvära Möten. Om utbildning och kritiskt lärande, 155-168. (Södertörn Studies in Education 1.) Stockholm: Södertörns högskola.

\section{Buchardt, Mette \& Pirjo Markkola \& Heli Valtonen (eds)}

2013 Education, State and Citizenship: NordWel Studies in Historical Welfare State. Research 4. NordWel: Helsinki.

2013 The School Curriculum and the Transformation of the State/Church Relation in 'the North' since the Early 20th Century. A Nordic Secular Lutheran Welfare State Model? Paper presented at NCRE, Reykjavik 2013 - Symposium. Iceland.

\section{Böwadt, Pia}

2009 The courage to be: the impact of Lebensphilosophie on Danish RE. - British Journal of Religious Education, 31, (1), 29-39.

\section{Eriksson, Anna \& Anna Roskvist}

2005 'Det kan ju vara bra att veta hur dom har det där nere' - Gymnasieelevers förställningar om islam och islamundervisning. Unbublished Bachelor's thesis, University of Gothenburg.

\section{Hartman, Sven}

2007a Barns tankar om livet. Stockholm: Natur Kultur.

2007b The Development of the Swedish Educational System - Marie Carlsson \& Annika Rabo \& Fatma Gök (eds), Education in 'Multicultural' 
Societies: Turkish and Swedish Perspectives, 257-265. (Swedish Research Institute in Istanbul Transactions 18.) London: I. B. Tauris.

2011 Perspektiv på skolans religionsundervisning. - Malin Löfstedt (ed), Religionsdidaktik: Mångfald, livsfrågor och etik i skolan, 19-34. Lund: Studentlitteratur.

Jensen, Tim

2008 RS based RE in Public Schools: A Must for a Secular State. - Numen $55,123-50$.

Johansson, Ylva \& Göran Persson

1996 Prop. 1995/96:200. Fristående skolor m.m. Utbildningsdepartementet: Rixlex.

Kilkelly, Ursula

1999 The Child and the European Convention on Human Rights. Dartmouth: Ashgate.

Lilja, Anna-Theodora \& Ewa Sunnercrantz

2005 'Nu ska jag säga en ganska smart sak tycker jag' - en kvalitativ intervjustudie av 10 gymnasieelvers uppfattningar om och attityder till religionskunskapsämnet. Unbublished Bachelor's thesis, University of Gothenburg.

\section{Lofland, John}

2006 Analyzing Social Settings: A Guide to Qualitative Observation and Analysis. Belmont: Wadsworth.

\section{Löfstedt, Malin}

2011a Inledning. - Malin Löfstedt (ed.), Religionsdidaktik: Mångfald, livsfrågor och etik $i$ skolan, 9-18. Lund: Studentlitteratur.

2011b Livsfrågor på gott och ont. - Malin Löfstedt (ed.), Religionsdidaktik: Mångfald, livsfrågor och etik i skolan, 51-64. Lund: Studentlitteratur.

2011c Mångfald, berättande och livsfrågor. - Jenny Berglund \& Gunilla Gunner (eds), Barn i religionernas värld, 210-224. Stockholm: Liber.

\section{Osbeck, Christina \& Henry Cöster}

2005 Is 'Ground of Values' a Religion? About training world views i a non confessional school. Paper presented at the 8th Nordic Conference on Religious Education: Religion, Spirituality and Identity, Helsinki, Finland.

\section{Otterbeck, Jonas}

2005 What is a reasonable demand? Islam in Swedish Textbooks. - Journal of Ethnic and Migration Studies 31 (4), 795-812.

\section{Skogar, Björn}

2005 Bildning och religion - en lärarutbildares perspektiv. Stockholm: Högskoleverket. 
Skollagen i praktiken - Motiv och kommentarer

2005 Stockholm: Svensk facklitteratur.

\section{Skolverket}

1994 Curriculum For the Compulsory School System, the Pre-School Class and the Leisure - Time Centre LPO 94. Stockholm: Skolverket.

2011a Curriculum for the compulsory school, preschool class and the leisure-time centre. Stockholm: Skolverket.

2011b Curriculum for the upper secondary school. Stockholm: Skolverket.

2001 Syllabuses for the compulsory school. Stockholm: Skolverket.

Svanberg, Ingvar \& David Westerlund

2011 Religion i Sverige. Stockholm: Dialogos.

Svensson, Jonas

2010a Björklunds omarbetning rimmar illa. - Svenska Dagbladet 13 Oct. 2010. 2010b Mycket skrik för lite ull... - Smålandsposten, 14 Oct. 2010.

\section{Thurfjell, David}

2011 Religionswissenschaft and the challenge of multi-religious student groups. - Religion 41 (2), 209-16. 